\title{
O MEMORIAL DO FRIGORÍFICO ANGLO DE PELOTAS: \\ UM LUGAR DE MEMÓRIA NO FRIO ESPAÇO DO ESQUECIMENTO
}

\author{
Francisca Ferreira Michelon' \\ Universidade Federal de Pelotas
}

\section{RESUMO:}

Compara-se a trajetória do Frigorífico Anglo de Pelotas com a do Frigorífico de Fray Bentos, Uruguai, observando no segundo caso o surgimento do Museo de la Revolución Industrial. Aplica-se - conceito de lugar de memória para entender parte do processo de patrimonialização do contexto do frigorífico uruguaio. Observa-se como o mesmo conceito pode justificar um memorial dentro da Universidade Federal de Pelotas, que adquiriu parte da planta industrial do Frigorífico Anglo e a adaptou para uso acadêmico.Advoga-se que a vontade de memória sobrevive quando o lugar de memória se institui coletivamente.

PALAVRAS-CHAVE:

Museu. Memorial. Memória. Frigorífico Anglo.

\begin{abstract}
:
Is compared the trajectory of Anglo Pelotas Refrigerator with the one of the Fridge of Fray Bentos, in Uruguay, observing in the latter case the appearance of the Museo de la Revolución Industrial. Is applied the concept of memory's place to understand a section of the patrimony of the Uruguayan context of the refrigerator. Is observed how the same concept can justify a memorial in the Federal University of Pelotas, which acquired part of the Refrigerator Anglo's industrial plant and adapted for academic use. The argument is that the memory will survive when the memory's place is established collectively.
\end{abstract}

\section{KEY-WORDS:}

Museum. Memorial. Memory.Anglo Fridg.

I Doutora em História. Coordenadora adjunta e professora do Programa de Pós-Graduação em Memória Social e Patrimônio Cultural da Universidade Federal de Pelotas. Coordenadora do projeto de implantação do Memorial do Anglo da UFPel. 


\section{Introdução}

A situação que sugeriu a análise que se desenvolve neste texto ocorreu sob a observação do que vem a ser o lugar onde foi, em um passado recente, o Frigorífico Anglo de Pelotas. Desde o final do ano de 2005, parte da extinta planta industrial desta, que foi uma grande indústria da cidade, é ocupada pela Universidade Federal de Pelotas. No conjunto onde se localizavam os prédios do abate, câmaras frigoríficas e processamento do animal abatido há

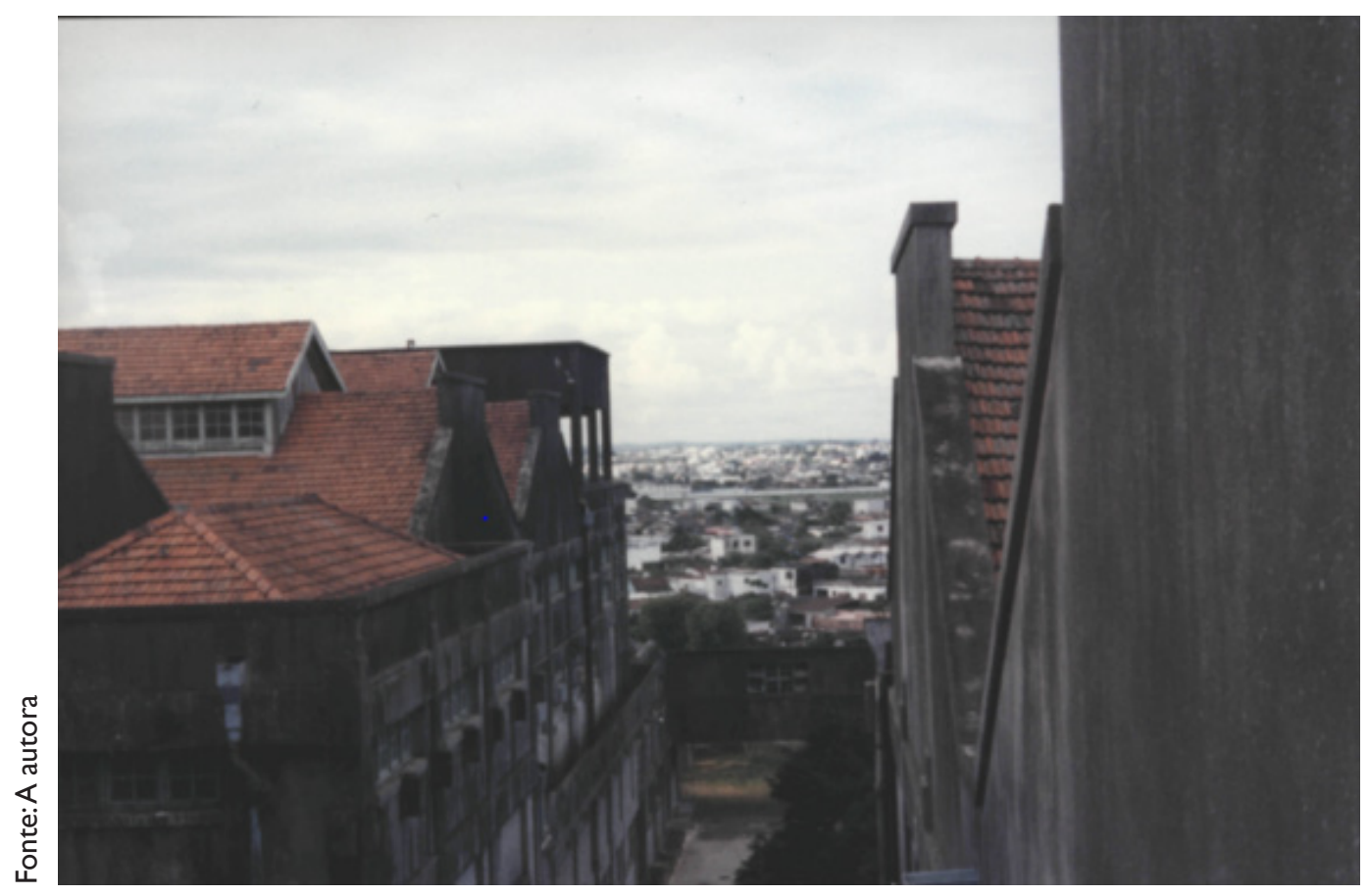

Figura I - Fotografia de dentro do prédio das câmaras frigoríficas.

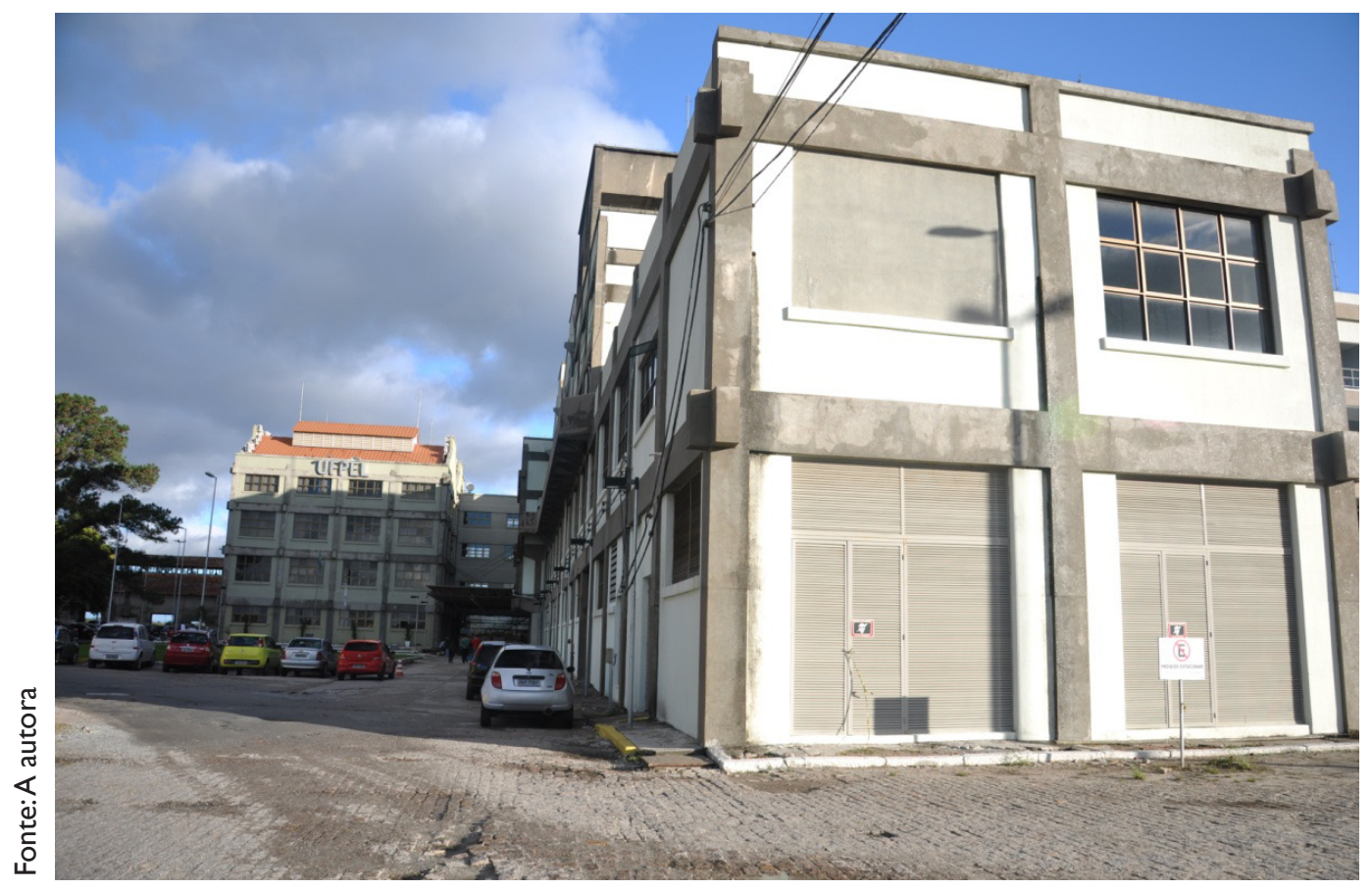

Figura 2 - Fotografia em posição inversa de enquadramento em relação à foto da figura I. 
faculdades e setores da administração central. Interiormente, a reforma realizada para esses fins alterou o prédio significativamente, mas a visão exterior do conjunto permanece com o mesmo volume, contorno e proporções das aberturas. Vendo-se fotografias tomadas em 1997 e no presente (Figuras I e 2), apesar da diferença no ângulo de registro da imagem, nota-se como o conjunto ainda é reconhecível. A Universidade cuidou para que se mantivesse exposta a estrutura de alguma parede das câmaras frigoríficas, de modo a se enxergar os materiais empregados na construção de prédios frigoríficos na década de 1940. Esse local foi destinado a ser um memorial do prédio.

Há, no mesmo andar, um conjunto de painéis com fotos e textos sobre os prédios históricos que pertencem ao patrimônio dessa Universidade, sendo que um desses se refere ao prédio do Frigorífico Anglo. Lamentavelmente, tanto as informações disponíveis sobre a parte da estrutura preservada e deixada aparente quanto o próprio painel. Não são insuficientes para esclarecer o público sobre o percurso desta fábrica, os impactos que exerceu sobre a cidade e os sentidos que a existência dos prédios de indústrias extintas ainda tem, primeiramente para a comunidade que habita as imediações do local e para a região. E a deficiência não está apenas na quantidade de informações passível de ser veiculada em tão exíguos suportes, mas ao conteúdo das mesmas, que afirmam a extinção do Frigorífico Anglo de Pelotas, como empresa e como lugar, silenciando equivocadamente um processo vivo, de mudanças, que se reatualiza e se recria pela memória de alguns milhares de pessoas que trabalharam no frigorífico ou tiveram parentes e amigos que também o fizeram.

Uma parte dessas pessoas reside ao lado da Universidade, em um conjunto que se denomina Vila da Balsa. Com os moradores dessa Vila, a Universidade desenvolve alguns projetos. Outra parte de ex-funcionários da empresa ou seus descendentes residem em setores diversos da cidade. Igualmente, é uma população numerosa, embora a totalidade de cada uma não esteja quantificada.

No âmbito dessa circunstância, o que se pretende é analisar a possibilidade de considerar o remanescente da planta do Frigorífico Anglo de Pelotas como patrimônio industrial. Deseja-se fundamentar e defender que o seu uso encontre soluções de assim mantê-la. A análise sustenta-se na observação comparativa entre a proposta do Memorial do Anglo, na UFPel e o surgimento do Museo de la Revolución Industrial, em Fray Bentos. Para tanto, inicia-se apresentando os dados já levantados pela pesquisa em andamento ${ }^{2}$, da qual é oriundo este estudo, para então confrontar o desenlace do Frigorífico Anglo de Pelotas com o do Frigorífico Anglo do Uruguai, que encerrou suas atividades quase duas décadas antes do que o brasileiro. Observamos, no percurso de ambos, as conexões que mantiveram com as cidades nas quais se localizaram. Por fim, as relações estabelecidas entre o processo de patrimonialização do frigorífico uruguaio e a proposição do Anglo pelotense como patrimônio industrial, sustentaram-se no entendimento de que em ambos os casos há uma condição de lugar de memória,

2 Patrimônio Industrial e Lugar de Memórias: o Frigorífico Anglo de Pelotas/Brasil e do Uruguai/Fray Bentos. Projeto de pesquisa lotado no Departamento de Museologia, Conservação e Restauro do Instituto de Ciências Humanas da UFPel, sob coordenação da autora do texto. 
tratado segundo o conceito proposto por Nora (1993) e tendo como objeto de investigação o inventário de ocorrências que o lugar propõe na trajetória que marcou o percurso de cada fábrica.

Ao fim e ao cabo, deseja-se propor um leque de possibilidades para a questão que tenta equacionar a potencialidade memorial que se percebe nesse lugar - o remanescente da planta industrial do Frigorífico Anglo de Pelotas - e a compreensão de que é um patrimônio industrial da cidade que pode sugerir um espaço museal, tal como o que se implantou dentro do complexo de Fray Bentos. Para desenvolver esse tópico, primeiro situa-se o leitor nos dados históricos que contextualizam os dois frigoríficos para, após, analisar-se como foi resolvida a questão museal em Fray Bentos. Busca-se, não obstante o oceano de diferenças que existem entre os dois casos, partir do exemplo uruguaio para observar as possibilidades do caso pelotense.

\section{O Frigorífico Anglo de Pelotas}

É possível que um pouco de surpresa e concretude ajude a aguçar a atenção do pesquisador para os dados, oportunizando novos contornos para as conclusões às quais se pode chegar. $O$ que aconteceu quando se soube que a reforma do prédio do Frigorífico Anglo havia segredado espaços, foi uma surpresa.

Por uma fenda vertical na parede com não mais de $25 \mathrm{~cm}$ de largura, ingressou-se em um lugar totalmente escuro. A luz do celular iluminou a sala e as passagens que se seguiram. Esse lugar era $\circ$ antigo conjunto de câmaras frigoríficas. Seguindo-se e passando-se de uma a outra, chegou-se a uma grande área de luz, que ingressava pelas janelas do andar e pela enorme abertura em uma das paredes, pela qual se via o espelho de águas do canal São Gonçalo. Pedaços das paredes estavam no chão e neles inscrevia-se a técnica construtiva de isolamento térmico, empregada nessas construções em meados do Século $X X$. Os trilhos de ferro no teto e os encanamentos de congelamento por amoníaco estavam visíveis. $O$ achado foi uma surpresa e não o resultado de uma procura. Mesmo assim, sentiu-se a felicidade de um arqueólogo que se depara com um fóssil revelador. Naquele momento, constatou-se que o Anglo continuava resistindo ao esquecimento que os novos usos impunham ao conjunto. Ele existia quase como um ente biológico que refuta a morte. Foi assim que se sentiu, sabendo-se bem que concreto, ferros, tijolos, cortiça e tudo o mais que estava ali, não vive, portanto, não sente, não lembra, não lamenta. Isso, só o pensamento humano faz.

A história desse Frigorífico tem mais de 90 anos, pois inicia com um empreendimento ousado e uma aposta alta que redundou em equivalente fracasso. O empreendimento foi a construção do Frigorífico Sulriograndense iniciada em 1918 e concluída no ano seguinte, quando se anunciava intensa crise no Banco Pelotense, maior acionista da companhia mantenedora. À sombra da falência, os investidores viram na proposta de compra apresentada pelo poderoso capital inglês do Grupo Vestey Brothers a solvência para o prejuízo que se anunciava. Assim, em 1921, a promessa de uma indústria frigorífica nacional do Rio Grande do Sul exauriu-se, dando lugar à instalação do frigorífico Anglo na cidade.

Efetivamente, esse empreendimento só iniciaria em 1943, quando foram inauguradas as novas instalações do Frigorífico. A distância entre as datas de construção deste e da planta industrial de Fray Bentos justifica muitas diferenças. Comparando ambos, a unidade de Pelotas foi bem mais modesta do que a uru- 
guaia. Mesmo assim, a previsão do número de abates e de processamento de animais era alta e se supõe que possa, desde o começo, ter empregado, diretamente, mil funcionários ao ano. Não há, ainda, documentos que comprovem tais dados. Era uma produção de safra e, portanto, havia sazonalidade na fabricação dos produtos. Regularmente, havia períodos de alta produção e eventualmente, por razões de mercado, esses períodos alargavam-se e intensificavam-se. Também a ocupação dos prédios era muito funcional. Sendo uma indústria voltada para o mercado exterior, era cadenciada pela demanda das exportações e fiscalizada pela vigilância federal, ou seja, sujeita a regras exigentes e cambiantes. $O$ atendimento a essas regras impunha mudanças rápidas, algumas oriundas do ingresso de novos equipamentos e métodos de produção. Assim, quando se pensa em recompor o uso do espaço, refere-se a uma eleição que deverá focalizar em um determinado período em detrimento de outros. Um exemplo simples pode ser dado pelo uso do uniforme. Até meados dos anos de 1970, os funcionários ingressavam e partiam da fábrica vestindo o uniforme. Aqueles que trabalhavam na sala da matança e nas áreas de processamento da carne costumavam ter o uniforme muito manchado. Alguns relatos referem o trânsito dos funcionários nas ruas, após o expediente, com as roupas brancas estampadas de manchas escuras. Quando as normas sanitárias proibiram o uso do uniforme fora da fábrica, o Frigorífico instalou, em um prédio já existente, o vestiário e em outro a lavanderia. Os funcionários tiveram que se adaptar a uma nova dinâmica de ingresso e saída.

O ritmo de trabalho era intenso, cadenciado e muito supervisionado. No entanto, cada setor tinha as suas particularidades e os setores periféricos poderiam mudar ou deixar de existir conforme as necessidades da grande indústria. Essa pluralidade de aspectos torna complexa qualquer narrativa. Há numerosas formas de abordar os fatores técnicos, econômicos e sociais que implicam, ou podem implicar no que se ousa chamar a memória desse lugar. E, mesmo, diferentes disciplinas poderão narrar a existência de tal ambiente de formas diferentes.Ainda assim, alguns aspectos pela generalidade ou profundidade com que se apresentavam, são mais indicadores ou sugestivos do panorama do que era, ao longo de sua existência, a vida dentro dessa fábrica.

O fato é que, na sua história que não foi tão curta, mas durou bem menos do que a unidade de Barretos e nem tão impactante na vida social de uma cidade como foi a unidade de Fray Bentos, houve muitas ocorrências. Elas se referem a eventos econômicos. Estão atreladas à trajetória da industrialização da carne e a refletem indiscutivelmente. São testemunhos do desenvolvimento da tecnologia frigorífica, indicam o percurso econômico dos países ao sul das Américas, enfim, participaram da história social desse país. Sobretudo, são ocorrências de muitas vidas, de muitas gerações. Nos depoimentos recolhidos, evidencia-se que os operários permaneciam quantidade considerável de horas na fábrica quando havia a possibilidade de ganho extra. Havia intenso convívio social. Muitos conheceram suas futuras esposas e seus futuros maridos e no local de trabalho, ou durante os curtos intervalos ou, ainda, nas ocasiões sociais de reunião dos operários. Era comum os filhos dos operários trabalharem no frigorífico. Essas situações, comuns nas fábricas, sugerem que as famílias acabavam por criar laços com esse espaço. Não foi raro encontrar ex-trabalhadores que tiveram toda sua vida produtiva anelada ao frigorífico. E mesmo sabedores das condições deletérias inerentes a algumas atividades, não culpavam o seu trabalho pela perda da saúde, que ocorria invariavelmente. $E$, evidente, o contrário também sucedia: havia os ressentimentos, merecidos ou não. 
No final dos anos de 1980, a produção já era pouca.A função de matadouro terminou nessa década e pouco antes de fechar, vários produtos já não eram mais fabricados. Como em tantos outros casos, o grupo encerrou a fábrica e a vendeu. A venda ocorreu no início da década de 1990. Os funcionários tentaram reativar parte das funções da fábrica, em vão. $O$ silêncio caiu sobre um lugar que durante cinquenta anos não silenciou, por pouco tempo que fosse. Sem máquinas, sem animais, sem mortes, sem produção, os barulhos que se faziam eram eventuais, de ocupações menores, de visitas anônimas, de pessoas autorizadas ou não, em afazeres passageiros. No entanto, durante essa década e meia em que nada parecia acontecer, o nome Anglo continuava altivo no frontão do prédio onde antes se produziam as conservas. Lá ficou, até que entre os anos de 2005 e 2006 a Universidade Federal de Pelotas passou a ser a proprietária do local.

\section{O Frigorífico Anglo de Fray Bentos}

No formulário de apresentação da lista indicativa do Uruguai da Paisagem Cultural-Industrial Fray Bentos (COMISIÓN DE GESTIÓN DEL ANGLO, 20I0, p. 2) o texto informa que a denominação se refere a um conjunto de elementos nos quais interagem fatores naturais com formas e expressões culturais, advindas da ocupação do território por atividades fabris, que impactaram na constituição da organização social dos grupos estabelecidos neste lugar. A pecuária e, em menor escala, a agricultura, estão na base da ocupação dessa área e antecedem a instalação dos primeiros saladeiros, em meados de 1850. No entanto, a fase efetivamente industrial no território, inicia em 1865, com a instalação da Liebig's Extract of Meat Company Limited (LEMCO). Tal fato sublinha que a pecuária foi a atividade determinante na organização social e econômica do Uruguai, modelando as suas paisagens rurais e os seus contornos sociais (SENA, 2012, p. 49). A LEMCO triunfou soberana no Uruguai até metade da década de 1920, e foi responsável por fazer o nome de Fray Bentos tornar-se conhecido na Europa, o continente onde o extrato de carne era consumido em vários países.

Em agosto de 1924, a empresa foi arrendada pelo GrupoVestey Brothers e mudou seu nome para Frigorífico Anglo del Uruguay (EL OBSERVADOR, 201 I, p. 18). Tem início a era frigorífica e, como consequência, a gama de produtos oferecidos aumentou. A máxima "do boi só se perde o mugido", passou a circular como um lema da missão dos frigoríficos de capital estrangeiro, nos quais o sistema produtivo taylorista envolvia técnica e tecnologia no aproveitamento quase máximo da matéria prima (figura 3).

O grupo Vestey comprou o frigorífico em Pelotas antes de comprar a LEMCO no Uruguai, no entanto, a unidade uruguaia foi ocupada em seguida e a planta industrial ampliada com a construção de novos prédios adequados ao processamento de 3600 animais por dia, entre bois e ovelhas (BERNHARD, 1970, p. 20). No mesmo ano da compra e do início das obras, a empresa passou a agenciar a vinda de imigrantes para atuar como funcionários da fábrica. Em seu estudo nos arquivos do Museo de la Revolucíon Industrial, o historiador Douredjian quantificou que entre o ano da compra da fábrica até 1934, ingressaram trabalhadores oriundos de 20 países diferentes, compondo em pouco mais de duas décadas um mosaico de etnias, dentre as quais predominavam 44 nacionalidades (DOUREDJIAN, 2009, p. 55-56). Evidentemente, a base da formação da classe trabalhadora nesta região uruguaia foi de imigrantes, e o grande responsável pelo fenômeno foi o frigorífico Anglo (TAKS, 2009, p. 2 I I). 


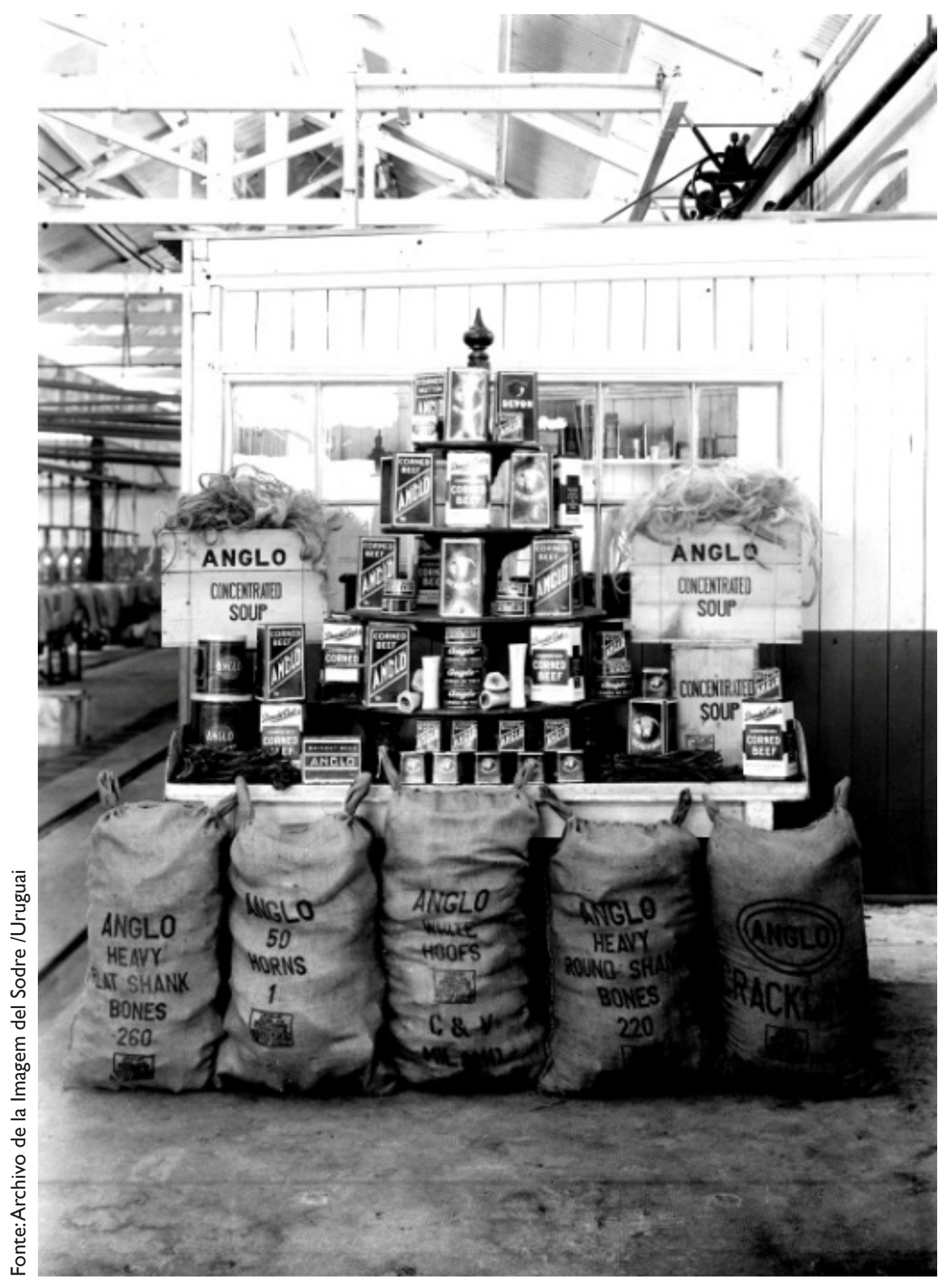

Figura 3 - Fotografia de alguns dos produtos exportados pelo Frigorífico Anglo de Fray Bentos: além dos enlatados, exportavam-se ossos, chifres, cascos e torresmo.

Portanto, enquanto a unidade pelotense permanecia inativa, a uruguaia povoava parte da região de Rio Negro e passava, como integrante do trust dos "big four", a monopolizar a indústria e o comércio da carne no Uruguai (BERNHARD, 1970, p. 20-24), com igual ingerência na agricultura. A empresa produzia em torno de 200 tipos de produtos de origem animal e vegetal.

Não é difícil supor o desastre econômico e social que o fechamento da fábrica provocou em dezembro de 1967. Nesse ano, o grupoVestey Brothers anunciou que fechava o Frigorífico Anglo e colocou a planta de Fray Bentos à venda. Praticamente, 
toda a população da cidade trabalhava no frigorífico e grande parte da região de Rio Negro vivia do fornecimento de matérias e serviços para a empresa. $O$ governo uruguaio não encontrou outra forma de evitar um desastre social, senão a de comprar a obsoleta planta do grupo inglês. O perverso golpe final sobreveio em 1969, quando o Ministério da Agricultura e Alimentação britânico proibiu a importação de carnes do Uruguai alegando que os rebanhos do país estavam infectados com a febre aftosa. Nesse ano, cessam em definitivo as atividades do Anglo como frigorífico e, dois anos após, como matadouro, determinando que o ano de I97I tenha sido aquele no qual o imenso complexo deixou de operar (DOUREDJIAN, 2009, p. I7). Como em Pelotas e em tantos outros casos, onde grandes fábricas fecharam suas portas partindo para investimentos ou lugares nos quais o lucro seria mais vantajoso, a população de trabalhadores tentou reativar algumas das funções do frigorífico, caindo, invariavelmente, no fracasso. Segundo a historiadora Campadónico ([2000?], p. I0I), a última tentativa em usar industrialmente parte do complexo ocorreu em 1979, quando uma empresa árabe arrendou a planta industrial, sem, no entanto, conseguir fazê-la operar. Em 15 de outubro deste ano, as portas daquele que foi o maior complexo industrial da região foram definitivamente fechadas.

\section{De lugar de trabalho a lugar de memória}

Guardando-se as devidas proporções, a história de ambos os frigoríficos, em Pelotas e em Fray Bentos, seguiram a mesma trilha, em parte porque se tratava de investimento do mesmo grupo empresarial e em parte porque a trajetória da indústria frigorífica foi muito semelhante em todos os países da América do Sul. O que vem após o fechamento das fábricas, é que é peculiar a cada um.

Da forma como o grupo Vestey Brother implantou o frigorífico na província de Rio Negro, a vida da cidade de Fray Bentos e do entorno se dava de acordo com existência desta fábrica. As palavras Anglo e Fray Bentos pareciam designar a mesma coisa no Uruguai, como ainda hoje parecem. No entanto, tudo mudou, embora a paisagem seja a mesma. Passados dez anos do seu fechamento irreversível, o complexo fabril e o bairro operário foram decretados Monumento Histórico Nacional. Em 2005, inaugurou-se no coração do complexo, no prédio construído no século XIX pela LECOM, o Museo de la Revolución Industrial e em 2008, ampliou-se a área protegida na resolução de 1987, nominando-a, então, Sistema Patrimonial Industrial Anglo. Criou-se a Comisión de Gestión Anglo, que em 2010 apresentou o projeto Paisaje Cultural Industrial Fray Bentos na lista indicativa do Uruguai perante à UNESCO, com fins de obter a declaração de Patrimônio Cultural da Humanidade. No momento em que se escreve este texto, a proposta se encontra classificada como projeto piloto, junto com outras nove em todo o mundo e aguarda o resultado da declaração para janeiro de 2014. Conclui-se que quando todo o trabalho cessou, surgiu a memória.

A cidade de Pelotas já tinha 120 anos de história quando o frigorífico foi inaugurado. Era, desde a origem, uma cidade industrial, que já havia, em outra época, experimentado um período de riqueza. Assim, o Anglo em Pelotas não teve nem o impacto, nem a hegemonia que exercia em Fray Bentos. Muitos outros aspectos são diferentes entre as duas unidades: a vila que se formou ao lado da fábrica surgiu de modo espontâneo. $\mathrm{Na}$ década de 1940 as grandes empresas não construíam mais habitações para seus operários. No entanto, tal como descreve a historiadora Janke (20I I), parte dos trabalhadores encontrou as formas de construir suas casas no terreno adjacente ao frigorífico. Em uma escala reduzida, essa comunidade fabril viu o frigorífico fechar suas portas e amargou a falta de trabalho e o abandono.As vãs tentativas de reativar algumas funções do complexo também foram fato em comum a ambas as comunidades.A grande diferença é que o fato memorial em Fray Bentos foi, 
por necessidade premente, chancelado desde o início pela Nação. No entanto, apesar das diferenças, o caso de Fray Bentos opera como um imenso espelho no qual o Anglo de Pelotas pode enxergar-se como parte do reflexo. Diante dessa circunstância é que se analisa o surgimento do Museo de la Revolución Industrial, para pensar comparativamente a condição que deve, ou pode, ter o Memorial do Anglo da UFPel.

A memória encontra seu lugar em qualquer lugar. Que seja esse grande ou pequeno, perto ou longe, físico ou imaterial. $O$ que importa é que o lugar de memória seja a ritualização do que resta de um tempo findo, incansavelmente presentificado pela lembrança. $O$ trabalho da memória é o rito, evocação que revivifica as coisas de outro tempo. Mas como tudo o que é vivo, a memória precisa do seu espaço. A vida sobrevive: em Fray Bentos, a cidade que vivia do frigorífico foi incorporando-o até que, no presente, o frigorífico sobrevive na memória da cidade. Ela deixou de ser o entorno para ser o todo.

O Museo de la Revolución Industrial foi instalado no edifício construído em 1872, pela LEMCO, onde se produzia o guano, fertilizante orgânico cuja fórmula foi inventada por Liebig. $O$ discurso museal desta instituição relaciona o espaço da planta industrial com a constituição social do município. A visitação ao museu é proposta de modo que o visitante possa ampliar a visita. Do museu pode seguir para o espaço da fábrica, passando pela grande casa das máquinas, pela sala da matança, pelos setores produtivos, pela conexão aérea que conduz até o enorme edifício das câmaras frigoríficas. Poderá finalizar o percurso ascendendo ao topo deste prédio de onde pode contemplar a magnífica paisagem do Rio Uruguai tocando as margens da cidade. Ou seja, o passeio sugere que o visitante conheça a extinta fábrica em um trajeto linear e conclua o percurso contemplando o horizonte (Figura 3). Portanto, é um discurso que retoma a ideia da trajetória que estava dada desde a fundação da LEMCO: de Fray Bentos para o mundo. Essa grandiosidade pode ser entendida, na perspectiva memorial, como a intensidade que o passado vai adquirindo na construção que um coletivo faz da própria história.

Figura 3 - Fotografia tomada do alto do prédio das câmaras frias do extinto frigorífico Anglo em Fray Bentos. Vê-se, parcialmente, a extensão de um dos lados do complexo, com ênfase para a Casa Grande e para parte do bairro operário e ao fundo, a cidade.

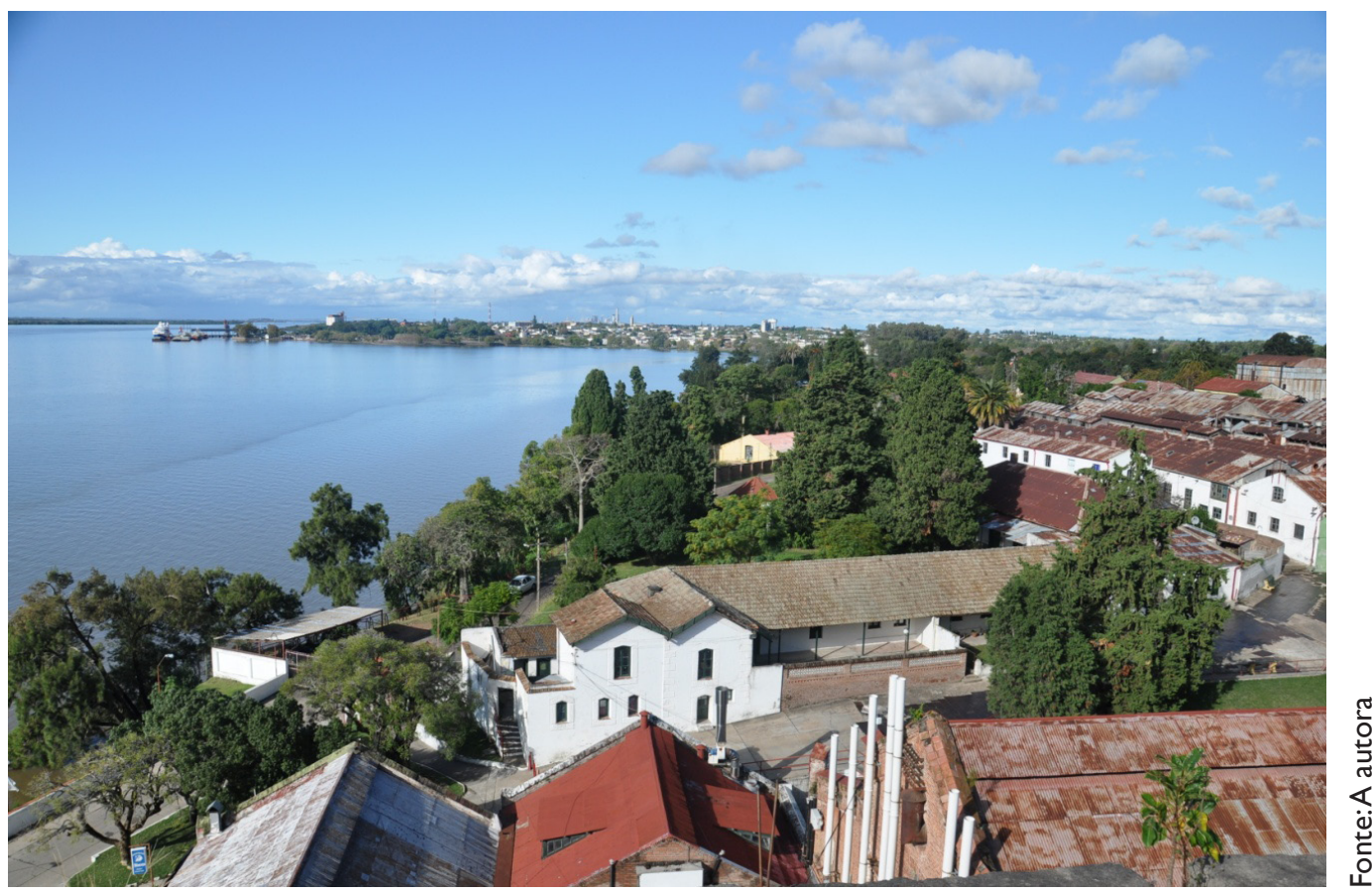


Esse processo de ressignificação do passado está, em geral, presente em todos os projetos de requalificação de espaços históricos. No caso de Fray Bentos, o viés que perpassa o discurso museal, também aparece em outra proposta, apresentada pelos arquitetos Ricardo Piazza e Mauro Delgrosso. Ambos elaboraram projetos de intervenção no edifício das câmaras frias. Na publicação que registra a proposta, constata-se o intenso trabalho de levantamento do edifício e, também, a visão patrimonial dos seus proponentes, que se expressa na definição que fazem do prédio:

La enorme magnitud del edificio de cámaras Frías (freezer building) del Frigorífico Anglo, poco común en establecimientos aún mayores que éste, bien nos hacen pensar en la prioridad y la importancia que tuvo para la nueva empresa a partir de la década del 20, la exportación de carne roja (Uruguay for Export, como ilustraba Zitarrosa en su 'Guitarra Negra'). [...] La combinación de su excelente puerto y este gran depósito de carne fría, cortada con los distintos cortes que el mercado exigia (tarea que debido a la cadena de frío se realizaba dentro del edificio), permitía continuas exportaciones de carne roja directamente a los mercados de destino, europeos en su mayoría (PIAZZA, 20 I I, p. I I).

O discurso museal da visita ao complexo completa-se, no fim do passeio, com a paisagem vista de cima do prédio emblemático das câmaras frias. Nos projetos dos arquitetos, o grande edifício ganha paredes de vidro em alguns lugares e permitem a quem está dentro ver o horizonte no rio. Em ambos os casos, o frigorífico olha para além do seu lugar, olha para o mundo e parece querer afirmar que a paisagem cultural e industrial de Fray Bentos pertence à humanidade porque é capaz de reter aspectos que representam não apenas a sua cidade e o seu país, mas diferentes momentos da história das sociedades industrializadas. É uma paisagem que tem vontade de memória.

Esse discurso pode ser pensado, em diferente proporção, para o remanescente do Anglo em Pelotas. Ainda há elementos com força evocativa no que sobrou. E cabe ao memorial sinalizar a evocação. A expressão da memória necessita de forma para que se afirme como um lugar e preme pelo simbólico para ritualizar o passado. A função de um memorial não é diversa da de um museu: ambos entabulam discursos memoriais, empregam narrativas para presentificar determinado passado e ritualizam objetos, ideias, fatos e toda a sorte de manifestações nas quais a humanidade possa se reconhecer. No entanto, a forma não segue a função, neste caso. Se ambos querem ser lugar de memória, não o são da mesma forma, nem com o mesmo formato.

O pequeno memorial do Anglo, dentro do prédio onde funcionaram as câmaras frias do Frigorífico de Pelotas, deseja ser uma bandeira capaz de sinalizar-se como suporte para a memória.

\section{Conclusão: o grande espaço da memória que cabe em qualquer lugar}

Buscam-se os registros de todas as formas, porque a vontade de memória que nutre a condição viva da lembrança precisa deste jogo clarificado por Nora entre os lugares de memória e a história:

Se vivêssemos verdadeiramente as lembranças que eles envolvem, eles seriam inúteis. E se em compensação, a história não se apoderasse deles para deformá-los, transformá-los, sová-los e petrificá-los eles não se tornariam lugares de memória. É este vai-e-vem que os constitui: 
momentos de história arrancados do movimento de história, mas que Ihe são devolvidos [...] (NORA 1993, p. 13).

No entanto, se a finalidade de propor um memorial fosse a história dessa fábrica, o recurso empregado já seria um fracasso na origem. Não se deseja a história, mas a memória. E, se houvesse a dúvida de que um espaço tão escasso poderia limitar a amplitude de uma memória - que se deseja grande como a dor de um gigante mutilado - também esse memorial pareceria um caminho incompleto. Contudo, o objetivo não é reconstruir intelectualmente o passado, suscitando conhecimento em suportes impregnados de informação. Trata-se, sim, de propor estímulo à imaginação, para que ela possa ativar e tornar desejável a lembrança.

Faz-se aqui uma analogia entre o que se figura intencional nesta proposta e a imersão de sentidos que Didi-Huberman apresenta no abismal estudo sobre as poucas fotografias feitas por prisioneiros do Sonderkommando no campo de concentração de Auschwitz e encontradas, após o fim da guerra, junto à resistência polonesa. Foram quatro fotografias apenas, feitas em condições inexplicáveis, que apresentam cenas pouco nítidas. Sabe-se que são cenas dramáticas porque o inferno que registram foi narrado e evidenciado de muitas formas. Nessas poucas e frágeis imagens, a informação é abreviada, dada a condição na qual foram geradas e, visualmente, apenas insinuam a mórbida grandeza da carnificina que gostariam de ter registrado. São pobres evidências do fato histórico, mas poderosos instrumentos para a imaginação. $E$ como observa o autor:

Es poco, es mucho. Las cuatro fotografías de agosto de 1944 no dicen toda 'la verdad', por supuesto (hay que ser muy inocente para esperar eso de lo que sea, las cosas, las palavras o las imágenes): minúsculas muestras en una realidad tan compleja, breves instantes en un continuum que ha durado cinco años, sin embargo. Pero son para nosotros - para nuestra mirada actual - la verdad en sí misma, es decir, su vestigio, su pobre andrajo: lo que queda, visualmente, de Auschwitz (DIDI-HUBERMAN, 2004, p. 65).

Seja como for, tão inabordável é qualquer passado, que mesmo que se tenha um imenso espaço com incontáveis suportes, o que fará imaginar é a vontade de memória e o que fará lembrar é o convite à imaginação. $\mathrm{E}$ a vontade de imaginar é o que, habitualmente, leva o visitante ao museu, pois, como observou Molder "Não há imagem mais radicalmente virtual do que a imagem produzida pela mente. $\mathrm{Na}$ verdade, vemos, ouvimos, por meio dessas imagens, mas não a vemos nem ouvimos [...]" (MOLDER, 1997, p. 94).

\section{Referências}

BERNHARD, Guillermo. Los monopolios y la industria frigorífica. Montevideo: Ediciones de la Banda Oriental, 1970.

CAMPODÓNICO, Gabriela. El frigorífico Anglo: memoria urbana y social em fray bentos. [2000?]. Disponível em: <http://www.unesco.org.uy/shs/fileadmin/templates/shs/archivos/anuario2000/7-campodonico.pdf>. Acesso em: 07 jul. 2012.

COMISIÓN DE GESTIÓN DEL ANGLO. Formulario de presentación de lista indicativa República Oriental del Uruguay: paisaje cultural-industrial Fray Bentos. [S.I.: s.n.], 2010.

DIDI-HUBERMAN, George. Imágenes pese a todo: memoria visual del Holocausto. Barcelona: Paidós, 2004. 
DOUREDJIAN, Alberto. Sobre inmigrantes y frigoríficos: el Anglo y los trabajadores (1924-1954). Montevideo:Tradinco S.A., 2009.

El ObservadoR. Historias del bicentenario. Montevideo: [s.n.], 20I I.

JANKE, Neuza Regina. Entre os valores do patrão e os da nação, como fica o operário?: (o frigorífico Anglo em Pelotas: 1940- 1970). Pelotas: EGU, 201 I.

MOLDER, Maria Filomena. Matérias sensíveis. In: MURMÚRIOS do tempo: catálogo da exposição. Porto: CPF, 1997.

NORA, Pierre. Entre memória e história: a problemática dos lugares. Projeto História, n. I0, p. 07-28, dez. 1993.

PIAZZA, Ricardo C.; DELGROSSO, Mauro. El despertar de un coloso: un nuevo ciclo de vida para las cámaras frías del Anglo. Uruguay: Intendencia de Rio Negro, 2011 .

SENA, Leonardo Gómez. Huellas y paisajes de la ganadería em el território uruguayo. Revista Labor \& Engenho, v. 6, n. I, p. 49-72, 2012.

TAKS, Javier. La clase trabajadora y las obreras del Anglo. Revista Encuentros, p. 2II-230, 2009.

Agradecimentos pela permissão para uso das imagens ao Archivo Nacional de la Imagen del SODRE.

Artigo recebido em março de 2013. Aprovado em julho de 2013 